UDC 37.02

DOI https://doi.org/10.24919/2308-4863/42-3-29

Olga TSYGANENKO, orcid.org/0000-0002-0809-5978 Maritime English Lecturer at the English Language Department for Maritime Officers (Abridged Programme)

Kherson State Maritime Academy (Kherson, Ukraine) olga.tsyganenko@gmail.com

Olena SAVCHENKO, orcid.org/0000-003-1222-1647

Maritime English Lecturer at the English Language Department for Maritime Officers (Abridged Programme) Kherson State Maritime Academy (Kherson,Ukraine)heleleko@gmail.com

\title{
INTERACTIVE LEARNING USING MODERN INFORMATION TECHNOLOGIES AT FOREIGN LANGUAGE LESSONS IN HIGHER EDUCATIONAL INSTITUTIONS
}

The publication attempts to outline the theoretical and methodological principles of the use of innovative technologies in teaching a foreign language. The authors traced the mechanism of the formation of communicative competence when using pedagogical technologies in foreign language classes. Particular attention is paid to the problem of the specifics of the application of innovative technologies in teaching maritime English at a higher educational institution on the example of the Kherson State Maritime Academy. Innovation implies something new, facilitates the course and indicators of the educational process. Based on this, innovative pedagogical activity can be considered as a mechanism for the formation and mastery of pedagogical innovations using innovative forms of education. Innovative learning is an educational activity focused on dynamic transformations in the surrounding world, built on the formation of different forms of thinking, creative abilities, high socially adaptive abilities of a person. It is indicated that a significant task of teaching a foreign language in the current period of development of education is the formation of a communicative culture. The publication raises the following questions: the use of modern pedagogical technologies in the educational process in general and in teaching English, innovative pedagogical technologies, their advantages in teaching, the introduction of computer technologies and their function in the development of foreign languages. A short explanation and assessment of innovative pedagogical technologies in the process of teaching English and other academic subjects is given on the example of using the Moodle educational platform. The publication describes how the use of information and communication technologies allows us to reorganize the learning process and what basic goals of using information and computer technologies by teachers can be identified. The publication substantiates the main advantages of these technologies, which are that they allow to informatize the educational process, and most correspond to the requirements of modern education in higher educational institutions. The tasks of such training are based on the potential of the computer as a means of cognitive and research activity, guarantee a personality-oriented approach to learning, and favor the improvement of students' individual inclinations.

Key words: innovative technology, pedagogical innovation, pedagogical technology, communicative competence, Moodle, Kherson State Maritime Academy, English.

Ольга ЦИГАНЕНКО,

orcid.org/0000-0002-0809-5978 викладач морської англійської мови кафедри англійської мови з підготовки морських фахівиів за

скороченою програмою

Херсонської державної морської академії (Херсон, Україна) olga.tsyganenko@gmail.com

Олена САВЧЕНКО,

orcid.org/0000-003-1222-1647 викладач морської англійської мови кафедри англійської мови з підготовки морських фахівців за скороченою програмою Херсонської державної морської академії (Херсон, Україна) heleleko@gmail.com 


\title{
ІНТЕРАКТИВНЕ НАВЧАННЯ З ВИКОРИСТАННЯМ СУЧАСНИХ ІНФОРМАЦІЙНИХ ТЕХНОЛОГІЙ НА УРОКАХ ІНОЗЕМНОЇ МОВИ У ВИЩИХ НАВЧАЛЬНИХ ЗАКЛАДАХ
}

\begin{abstract}
Автори статті вдаються до спроби окреслити теоретичні й методологічні засади використання інноваційних технологій у навчанні іноземної мови. Автори простежили механізм формування комунікативної компетентності при використанні педагогічних технологій на уроках іноземних мов. Особлива увага приділяється проблемі специфіки застосування інноваційних технологій у викладанні морської англійської мови у вищому навчальному закладі на прикладі Херсонської державної морської академії. Інновачія передбачає щзось нове, полегшує хід $i$ показники навчального процесу. Виходячи із иъього, інноваційну педагогічну діяльність можна розглядати як механізм формування педагогічних інновачій та оволодіння педагогічними інноваціями із застосуванням інноваційних форм навчання. Інноваційне навчання - це навчальна діяльність, орієнтована на динамічні перетворення в навколишньому світі, побудована на формуванні різних форм мислення, творчих здібностей, високих сочіальних адаптаційних здібностей людини. Указується, щзо значним завданням викладання іноземної мови в сучасний період розвитку освіти є формування комунікативної культури. У публікації порушуються такі питання: використання сучасних педагогічних технологій у навчальному процесі загалом і в навчанні англійської мови, інноваційні педагогічні технології, їх переваги в навчанні, упровадження комп 'ютерних технологій $i$ їх функція в розвитку іноземних мов. Коротке пояснення й очінка інновачійних педагогічних технологій у прочесі викладання англійської мови та інших навчальних предметів дається на прикладі використання освітньої платформи Моодle. Стаття описує, як використання інформаційно-комунікаційних технологій дає нам змогу реорганізувати навчальний процес $і$ які основні иілі використання інформаційних і комп'ютерних технологій викладачами можна визначити. Стаття обтрунтовує основні переваги циих технологій, які полягають у тому, щзо вони дають змогу інформатизувати навчальний процес і найбільше відповідають вимогам сучасної освіти у вищих навчальних закладах. Завдання такого навчання базуються на потенціалі комп 'ютера як засобу пізнавальної та дослідницької діяльності, гарантують особистісно орієнтований підхід до навчання, сприяють удосконаленню індивідуальних нахилів учнів.

Ключові слова: інноваційна технологія, педагогічна інноваџія, педагогічна технологія, комунікативна компетентність, Моодlе, Херсонська державна морська академія, англійська мова.
\end{abstract}

Problem study. Creating a qualitatively different system of education in higher education institution is impossible without taking into account and using the potential of new learning technologies, among which a special place belongs to information and communication technologies based on the didactic potential of computer tools. They provide the necessary conditions for the activation of cognitive and language activities of each student, providing an opportunity to learn new material, obtain sufficient professional information, get acquainted with a large number of original texts to form the necessary skills and abilities.

The use of information technology reveals the enormous potential of the computer as a learning tool using multimedia training programs. The computer helps in:

- conducting testing;

- monitoring the educational process;

- the preparation of didactic materials;

- the use of Internet resources and services for classroom and independent work;

- the project activities of students.

Information technologies not only facilitate access to information and open opportunities for variability of educational activities, its individualization and differentiation, but also allow to reorganize the interaction of all subjects, to build an educational system in which the student would be an active and equal participant in educational activities (Modern school. A modern lesson. The use of information and communication technologies in the educational process).

Recent publication analyses. Well-known foreign and domestic scientists took part in solving the problem of formation of communicative competence when using pedagogical technologies in foreign language classes. In particular, P. Bekh considered the study of foreign languages in educational institutions from the standpoint of communicative orientation (Bekh, 2002: 34-40). O. Hretska researched the use of electronic encyclopedias in teaching foreign languages (Hretska, 2002: 38-40). New technologies in the study of foreign languages by students were the subject of scientific research by T. Husak (Husak, 1999: 45-46). In turn, S. Konovets analyzed creative educational technologies (Konovets, 2005: 20-21). A. Petrovskyi and H. Kytaihorodska researching methods of intensive foreign language teaching touched upon certain issues of intensification of educational activities (Petrovskyi, Kytaihorodska, 1999).

The purpose of the article. The purpose of the article is to determine the theoretical and methodological principles of using innovative technologies in teaching a foreign language, as well as to explore the features of the use of innovative technologies in teaching English in higher education institution. Modern pedagogical technologies are aimed at changing the educational situation so that the teacher becomes 
a more attentive and interested interlocutor who will go side by side with the student in the learning process. A special place should be given to such forms of classes that ensure the participation of each student in the lesson, increase the authority of knowledge and individual responsibility of students for the results of educational activities. Teachers of Maritime English at the Kherson State Maritime Academy are actively trying to implement these forms in their pedagogical practice.

Main material presentation. Today, the introduction of computer technology in the educational process is an integral part of learning. It is generally accepted that the use of computer technology in education is inevitable, as it significantly increases the effectiveness of learning, the quality of knowledge and skills (Virtual school of professional development of a young teacher).

The use of information and communication technologies in the learning process allows us:

- to make this process interesting, on the one hand, due to the novelty and unusualness of this form of work, and on the other hand, to make it exciting and bright, diverse in form through the use of multimedia capabilities of modern computers;

- solve the problem of clarity of learning, expand the possibilities of visualization of educational material, making it more understandable and accessible to students to freely search for necessary educational material in remote databases through the use of telecommunications, which will further contribute to students' need for search;

- to individualize the learning process due to the presence of multilevel tasks, work independently with educational material, using convenient ways of perceiving information, which causes positive emotions in students and forms positive learning motives;

- to analyze and correct mistakes, adjust activities through the availability of feedback resulting in improved self-control skills;

- to carry out independent learning and research activities (modeling, project method, development of presentations, writing publications, etc.) developing creative activity in students;

Collaboration through personal blogs and websites provides a relationship between students and teachers. For example, teachers of the Kherson State Maritime Academy actively use the Moodle learning platform in their teaching, designed to unite teachers, administrators and students into one reliable, safe and integrated system to create a personalized learning environment (About Moodle).

Innovative forms of working with computer training programs in foreign language lessons include: learning vocabulary; pronunciation practice; study of dialogic and monologue language; study of writing; practice grammar skills. The possibilities of using Internet resources are huge. The easiest way to use the Internet is to use it as a source of additional materials for teachers and students. The Internet creates the conditions for obtaining any necessary information for students and teachers: scientific material, news, articles from newspapers and magazines, and more. At English lessons, you can develop reading skills and abilities using the materials of the global network to improve students' written language skills, replenish students' vocabulary, form students' motivation to learn English. The example of the use of the Internet at the lesson is the inclusion of QR-codes with the reference to text material for self-study by students in the "Sail Safe" coursebook for cadets and students of higher education in the field of "Sea and river transport" (Barsuk, Bondarenko, Vid, Kudryavtseva, Likhosherstova, 2021: 10, 40, 136, 168).

The purpose of learning a foreign language is the formation of communicative competence, educational and developmental goals, which are realized in the process of achieving this main purpose. The communicative approach implies learning to communicate and the formation of the ability to intercultural interaction, which is the basis of the Internet. The Internet is an international multinational, cultural society whose life is based on the electronic communication of millions of people around the world who speak simultaneously. We create a model of real communication by joining it in a foreign language lesson. Today, new methods using Internet resources are opposed to the traditional study of foreign languages. In order to teach communication in a foreign language, you need to create real life situations that will stimulate the study of the material. In the methodology it is called interactivity. The term "interactive pedagogy" is relatively new: it was introduced in 1975 by the German researcher Hans Fritz. Linguistic interpretation of the word, presented in foreign dictionaries, shows that the concepts of "interactivity", "interactive" came to us from the English language. Interactivity in learning can be considered the interaction of students, their stay in the mode of conversation, dialogue, joint action. Accordingly, in the literal sense, interactivity can be a method in which the learner is a participant who, together with others, does something: speaks, manages, models, writes, draws, i.e. does not act only as a listener, observer, but actively participates in the process personally creating it. The essence of interactive learning is that the learning process takes place only through constant, active interaction of all students (Pometun, Pyrozhenko, Bida, 2011: 5). 
The use of interactive learning technologies at different stages of a foreign language lesson is not only a way to increase students' motivation to learn a language, but also to improve the classroom atmosphere, which will promote cooperation and understanding between students and teachers. Mutual trust, equality, partnership in communication causes students to enjoy the learning process, the desire to participate in it. However, you need to constantly monitor the process of achieving goals, and to change tactics, look for and correct shortcomings in case of failure.

Interactive methods should not be an end in themselves; they should be a means to create a comfortable atmosphere that will allow you to implement a person-centered approach to learning.

Conclusion. Modern pedagogical learning technologies can be implemented through interactive learning. Interactive learning is, first of all, dialogical learning, during which teacher-student interaction takes place. Interactive teaching methods include the project method, pair work, group work, brainstorming, modular learning and more.

Thus, the Internet helps to develop spoken language skills by teaching students the real language, as well as providing a genuine interest in learning a foreign language, as interactivity not only creates reallife situations, but also gives students the impetus to respond on the situation with the help of a foreign language. Thus, the Internet develops the individual qualities of students and creates a favorable atmosphere for learning.

Teachers of the Kherson State Maritime Academy use the methods of presentations, video presentations and projects in their pedagogical practice. Presentations in foreign language lessons allow us to combine the use of multimedia and the necessary language material. The advantage of presentations is that they can be used at any stage of studying the topic. The project method in world pedagogy is not a new invention. Probably, this method is, in our opinion, the most interesting and motivating. The project is based on a certain problem. The element of creativity makes project work purely individual. Working on the project, students do a little research work: searching and processing material in textbooks and the Internet, highlighting the most important pieces of information, finding illustrations, preparing the project for presentation at the lesson.

Thus, information technology is a requirement of today that allows us to create a society based on knowledge. They simplify communication and cooperation. A society that cares about its future must be aware of the enormous opportunities brought by new information technologies and learn to apply them competently, especially in education.

\section{BIBLIOGRAPHY}

1. Бех П. 3 позицій комунікативної орієнтації. Іноземні мови в навчальних закладах. 2002. № 1-2. С. 34-40.

2. Грецька О. О. Використання електронних енциклопедій у навчанні іноземних мов. Іноземні мови. 2002 . № 2. C. $38-40$.

3. Гусак Т. Нові технології у вивченні студентами іноземних мов. Рідна школа. 1999. № 10. С. 45-46.

4. Коновець С. Креативні освітні технології у практиці сучасної школи. Рідна школа. 2005. № 3. С. 20-21.

5. Петровський А. В., Китайгородська Г. А. До деяких питань активізації навчальної діяльності. Методи інтенсивного навчання іноземних мов. Київ : Дніпро, 1999. 471 с.

6. Застосування інтерактивних технологій у навчанні молодших школярів : методичний посібник для вчителів початкової школи / О. І. Пометун, Л. В. Пироженко, О. А. Біда та ін. Тернопіль : Навчальна книга «Богдан», 2011. С. 5.

7. Sail Safe: coursebook / S. Barsuk, V. Bondarenko, A. Vid, V. Kudryavtseva, V. Likhosherstova. Kherson : «STAR» PH, 2021. 230 p.

8. Віртуальна школа професійного становлення молодого педагога. URL: http://teacher.ed-sp.net/ (дата звернення: 27.06.2021).

9. Сучасна школа. Сучасний урок. Використання інформаційно-комунікаційних технологій у навчально-виховному процесі. URL: http://osvita.ua/school/lessons_summary/edu_technology/30549/ (дата звернення: 27.06.2021).

10. About Moodle. URL: https://docs.moodle.org/27/en/About_Moodle\#Built_for_learning.2C_globally (дата звернення: 27.06.2021).

\section{REFERENCES}

1. Bekh P. Z pozytsii komunikatyvnoi oriientatsii [From the standpoint of communicative orientation]. Foreign languages in educational institutions. 2002. № 1-2. Pp. 34-40 [in Ukrainian].

2. Hretska O. O. Vykorystannia elektronnykh entsyklopedii u navchanni inozemnykh mov [The use of electronic encyclopedias in teaching foreign languages]. Foreign languages. 2002. № 2. Pp. 38-40 [in Ukrainian].

3. Husak T. Novi tekhnolohii u vyvchenni studentamy inozemnykh mov [New technologies in the study of foreign languages by students]. Native school. 1999. № 10. Pp. 45-46 [in Ukrainian].

4. Konovets S. Kreatyvni osvitni tekhnolohii u praktytsi suchasnoi shkoly [Creative educational technologies in the practice of modern school]. Native school. 2005. № 3. Pp. 20-21. 
5. Petrovskyi A., Kytaihorodska H. Do deiakykh pytan aktyvizatsii navchalnoi diialnosti. Metody intensyvnoho navchannia inozemnykh mov [On some issues of intensification of educational activities. Methods of intensive foreign language teaching]. Kyiv: Dnipro, 1999. 471 p. [in Ukrainian].

6. Pometun O. I., Pyrozhenko L. V., Bida O. A. Zastosuvannia interaktyvnykh tekhnolohii u navchanni molodshykh shkoliariv: Metodychnyi posibnyk dlia vchyteliv pochatkovoi shkoly [The use of interactive technologies in the teaching of primary school children: A guide for primary school teachers]. Ternopil: Navchalna knyha «Bohdan», 2011. P. 5.

7. S. Barsuk, V. Bondarenko, A. Vid, V. Kudryavtseva, V. Likhosherstova. Sail Safe: coursebook. Kherson: "STAR” PH, 2021. Pp. 10, 40, 136, 168.

8. Virtualna shkola profesiinoho stanovlennia molodoho pedahoha [Virtual school of professional development of a young teacher]. URL: http://teacher.ed-sp.net/ (Last accessed: 27.06.2021).

9. Suchasna shkola. Suchasnyi urok. Vykorystannia informatsiino-komunikatsiinykh tekhnolohii u navchalnovykhovnomu protsesi [Modern school. A modern lesson. The use of information and communication technologies in the educational process]. URL: http://osvita.ua/school/lessons_summary/edu_technology/30549/(Last accessed: 27.06.2021).

10. About Moodle. URL: https://docs.moodle.org/27/en/About_Moodle\#Built_for_learning.2C_globally (Last accessed: 27.06.2021). 